\title{
Article \\ Perceived Discrimination of Highly Educated Latvian Women Abroad
}

\author{
Inese Šūpule $\mathbb{B}$
}

\section{check for} updates

Citation: Šūpule, I. Perceived Discrimination of Highly Educated Latvian Women Abroad. Adm. Sci. 2021, 11, 3. https://dx.doi.org/10. 3390/admsci11010003

Received: 16 October 2020

Accepted: 9 December 2020

Published: 23 December 2020

Publisher's Note: MDPI stays neutral with regard to jurisdictional claims in published maps and institutional affiliations.

Copyright: (c) 2020 by the author. Licensee MDPI, Basel, Switzerland. This article is an open access article distributed under the terms and conditions of the Creative Commons Attribution (CC BY) license (https: / / creativecommons.org/ licenses/by/4.0/).
Institute of Sociology and Philosophy, University of Latvia, LV-1050 Riga, Latvia; inese.supule@biss.soc.lv

\begin{abstract}
The aim of this paper is to answer the question of what factors lead to an increase in perceived discrimination in the workplace among highly educated Latvian women abroad. Although highly educated migrant women are privileged with regard to education, nonetheless, they face discrimination, lower wages, inferior working conditions, de-skilling and brain waste while working abroad. Based on the discussion on the relationship between sociocultural integration and discriminatory practices or perceived discrimination, and two competing theoretical propositions regarding the effects of integration on perceptions and experiences of discrimination, the article tests if attachment to the host country is related to perceived discrimination at work. The data source used for the analysis is a subsample of a quantitative survey of Latvian emigrants. The subsample $(\mathrm{n}=2332)$ includes Latvian women with a tertiary education who are first-generation emigrants from Latvia and who were working at the time of the survey. Results from binary logistic regression analyses reveal that a low attachment to the host country, financial difficulties coping with daily expenses, problems with recognition of an education certificate and lack of a written contract with the employer increase the likelihood of highly educated Latvian women abroad to claim unfair treatment in the workplace.
\end{abstract}

Keywords: perceived discrimination; highly skilled women; labor migration; Latvia

\section{Introduction}

The migration of highly skilled women is a growing migration-related phenomenon in many countries. For example, between 2000 and 2011, the number of tertiary-educated migrant women in OECD countries rose by 80\% (IOM/OECD 2014). Over the years, the body of knowledge on highly skilled migrant women has increased (Triandafyllidou and Isaakyan 2016). However, emigration of highly skilled women from Eastern Europe and particularly from Latvia is under-researched, with a few exceptions. Despite the apparent advantages enjoyed by highly educated migrants, especially among intra-EU highly skilled migrants, they also face the challenge of inter-cultural adaptation. Not only lowskilled, but also highly skilled migrants experience multiple social positionings in their countries of origin and in host countries, which translates into various gender- and classbased privileges and forms of discrimination (Bailey and Mulder 2017). Gender discrimination and ethnic discrimination or a combination of these factors delay full integration of immigrants. Although the gendered nature of migration has not been ignored in labor studies, the gendered dimensions of perceived discrimination have not yet been explored in detail, especially in the context of Latvian migrants. To fill the gap, this study focuses on the perceived discrimination of highly educated Latvian women abroad. The research question of the study is: what factors lead to an increase in perceived discrimination in the workplace among highly educated Latvian women abroad? Based on a quantitative analysis of survey data, this paper examines different background indicators, migrants' economic integration factors and attachment to the host country and their relation to perceived discrimination at work. The term "perceived discrimination" has been used throughout the paper to refer to a situation where an individual believes that she has been treated unfairly at her workplace. This study does not analyze actual employment discrim- 
ination of Latvian emigrant women, but focuses on individuals' subjective perceptions of employment discrimination (Andriessen et al. 2014).

Although highly educated migrant women are privileged with regard to education, their integration into the labor market is nonetheless shaped by gender norms and ethnically affected labor-market conditions (Grigoleit-Richter 2017). They face discrimination, lower wages, inferior working conditions, de-skilling and brain waste while working abroad. For example, employed highly skilled immigrants are almost twice as likely to be overqualified for their job as their native peers (OECD/EU 2015). However, sometimes immigrants initially do not perceive different practices as discriminatory, because their socio-economic opportunities in the host country are better than those in their countries of origin (Waters and Kasinitz 2013).

Taking into account that migration patterns from Eastern European countries like Poland, Lithuania and Latvia are somewhat similar (Grzymała-Kazłowska 2013), the analysis contributes to the gendered perspective of post-accession migration studies and the issues of discrimination. In this context, it is important to note that low levels of discrimination in destination countries are a significant pull factor, as women tend to migrate to countries where they can enjoy greater freedom and rights (Ferrant and Tuccio 2015).

In most studies, perceived discrimination has been studied from the host-country perspective (Portes et al. 1980; Aguirre et al. 1989; Brüss 2008; Estrada et al. 2008; Vancluysen and Van Craen 2010). A sending-country perspective on perceived discrimination has been neglected and is under-researched. One of the few studies on discrimination against Latvian migrant workers abroad (Tabuns 2019) indicates that 35\% of Latvian migrant workers have encountered some form of discrimination or unfair treatment in their workplace. The most common form of unfair treatment is an unfair salary: $18 \%$ have reported that they have been paid less than workers from the host nation for similar work. This study also reports that skilled and unskilled workers-as opposed to managers and professionals-are more likely to face discrimination at work. At the same time, the findings of this study are in line with previous findings (Mierina 2016) that Latvian emigrants evaluate the attitude of employers abroad as being better than that of employers in Latvia, where they face unfair treatment even more often. However, in his study, Tabuns (2019) does not touch upon the relationship between migrants' perceived discrimination and their integration in the host country and other factors.

The data source used for the analysis is a quantitative survey of Latvian emigrants, organized from August to October 2014. For the purposes of analysis, a subsample of highly skilled Latvian women has been developed, based on interpretation that highly skilled migrant is a migrant with a tertiary education. This subsample $(n=2332)$ includes only those Latvian women with a tertiary education who are first-generation emigrants from Latvia and who were working at the time of the survey. The exploratory study on subjective perceptions of employment discrimination aims to broaden the understanding of when discrimination is likely to occur. This is important in order to formulate relevant recommendations for anti-discrimination policy.

The article begins with a literature review of previous studies about the gendered nature of migration, perceived discrimination and integration into the host society. Section 3 of the paper reports on the contemporary migration trends of Latvians, the survey data, methods and analytical strategy used. After presenting the results of the analysis, the article closes with a discussion of the main results and conclusions.

\section{Literature Review}

Studies of discrimination of migrants that refer to the relationship between sociocultural integration and discriminatory practices or perceived discrimination offer different theoretical perspectives (Portes et al. 1980; Aguirre et al. 1989; Estrada et al. 2008; Vancluysen and Van Craen 2010).

One of the early theories that examined the relationship between assimilation and discrimination is the assimilation theory of Gordon (1964). He argued that there are several 
stages of assimilation, and that the last stages are absence of prejudice, absence of discrimination and absence of value and power conflict. Gordon (1964) and other followers of the assimilation theory had assumed that as members of minority ethnic groups assimilate into the dominant group, they perceive and experience lower degrees of discrimination directed against them from the majority.

Another theory is advocated by Portes et al. (1980), who suggest and argue the opposite: the more ethnic minorities integrate, the greater their perception of unequal treatment. In their study of Cuban and Mexican immigrants in the United States, they have tested two hypotheses, based on competing perspectives of the assimilation theory and the conflict consciousness theory, and found more support for the conflict consciousness theory. Their findings suggest that the better immigrants understand the host-country language and the more they endorse its values, the more skeptical they are of the realities of that society and of their actual condition within it (Portes et al. 1980, p. 220).

Based on the discussion on the relationship between sociocultural integration and discriminatory practices or perceived discrimination, and two competing theoretical propositions regarding the effects of integration on perceptions and experiences of discrimination, the following hypothesis will be tested during data analysis: The more migrants feel attached to the host society, the less discrimination they will perceive. Additionally, vice versa: those migrants who feel less attached to the host society will be more likely to report perceived discrimination. The possibilities to correctly test the conflict consciousness theory is somewhat limited in this article, because of data availability. Portes et al. (1980) in their study of Cuban and Mexican immigrants in the United States used data collected soon after their arrival in the United States and compared with answers 3 years afterward. The survey data used for the analysis do not provide such a methodology. Therefore, the main focus here is on testing the assimilation hypothesis.

Several studies on post-accession migration point out that EU8 migrants (EU8-the Czech Republic, Estonia, Hungary, Latvia, Lithuania, Poland, Slovakia, Slovenia) are on average better educated than natives and tend to be employed in positions below their education levels (Clark and Drinkwater 2008; Dustmann et al. 2010; Kaczmarczyk and Tyrowicz 2015). The study of the British labor market shows that EU8 migrants are employed mostly in basic occupations and thus earn on average considerably lower salaries than their British counterparts, although they are better educated (Kaczmarczyk and Tyrowicz 2015). In the study based on UK LFS data, Jakubiak (2015) has found that among post-accession migrants, Poles and citizens of the Baltic states are doing particularly badly compared not only to EU15 migrants but also to third-country nationals (e.g., Indian or Pakistani migrants). A study by Krystyna Iglicka on Polish post-accession migrants (2010) provide findings that the brain waste/over-qualification problem can be partly explained by the limited or complete lack of working experience of young tertiary-educated migrants from Poland. A recent study by Kaczmarczyk (2018) suggests that an explanation can be sought both in the lower level of skills that young tertiary-educated migrants possess (as compared to natives) and also to substantial wage discrimination on the British labor market between 2004 and 2014. Thus, the previous studies allow for the conclusion that EU8 migrants are facing earnings penalties and forced to work below formal qualification because of the lack of host-country-specific skills on arrival. The analysis of Dustmann et al. (2010) suggests that the labor market situation of immigrants substantially improves with time in the UK, in terms of both wages and labor force attachment. Thus, the degree of integration may rise with time and the acquisition of host-country-specific capital (Frattini et al. 2017). However, these trends should be analyzed in a comparative perspective, taking into account both migrants' ethnicity/ nationality and the time lived in the host society. Qualitative studies of second-generation migrants indicate that even those highly skilled who have obtained their education in the host country and are able to form networks and integrate culturally face marginalization and discrimination (Verwiebe et al. 2016; Yilmaz Sener 2019). For example, a study of Verwiebe et al. (2016) indicates multiple challenges for female second-generation 
graduates in the career-entry phase who experienced disadvantages due to their origins, age and gender.

Another aspect featured in this study is the effect of return intentions and attachment to the country of origin on perceived discrimination. In a neoclassical economic approach, immigrants are 'income maximizers' who have migrated in order to maximize their lifetime earnings. Return migration is therefore examined as a failure of planned migration, because the aim of getting a bigger income has not been achieved (Todaro 1969). In this case, perceived discrimination may have a correlation with return intentions. The disappointment related to perceived discrimination in the host country may foster the development of sentiments and attachment to the country of origin (Yilmaz Sener 2019). Therefore, it might be expected that those who have intentions of returning and have a strong attachment to the country of origin would be more likely to experience perceived discrimination.

The challenge of sociocultural integration may differ in the particular contexts of the host country, industry, employers, approaches to integration policies and other factors (Mulholland and Ryan 2014). Therefore the analysis examines not only attachment to the host country, but also different background indicators, migrants' economic integration indicators and their relation to perceived discrimination at work.

Different host countries, as well as different countries of origin and changing migration policies, provide the context in which we can situate migration experiences among the highly skilled. Labor migration policies set the framework at the macro level for both highly skilled migrants and their employers, and the gender dimension of these policies has been scrutinized by many scholars (Boucher and Cerna 2014; Cerna 2011; Kofman 2014; Triadafilopoulus 2013). As the challenge of inter-cultural adaptation may differ in the particular contexts of the host country, perceived discrimination among highly educated women migrants is analyzed in the contexts of the different countries to find out if perceived discrimination is occurring in some countries more often.

\section{Empirical Methodology}

\subsection{Research Context}

When characterizing the Latvian context, the problem of a relatively small and declining population should be mentioned. Since 1990, the country's population has decreased by more than 700,000 persons, as a result of emigration and low birth rates (CSB Latvia 2020c). Before Latvia's accession to the EU, emigration from Latvia occurred at rather low rates, while after EU accession in 2004 and access to the labor markets of the UK, Ireland and Sweden, emigration flows from Latvia have increased and the outflow from Latvia has almost tripled (Hazans 2018). The economic crisis in Latvia of 2008-2009 and its economic and social consequences were the main reasons for the new emigration wave.

The study on the trends, drivers and policy responses in relation to brain flow in Europe between 2004 and 2016 (ICF 2018) shows that the countries sending intra-European movers are Poland, Slovakia, Estonia, Bulgaria, Croatia, Latvia, Portugal, Lithuania and Romania. Higher salaries abroad are an important reason for most labor emigration, and destination countries usually offer better working and living conditions compared to sending countries. The most popular destination countries among Latvians are European Union member states (the majority head to the UK, Ireland and Germany), as well as the European Free Trade Association (EFTA) countries (mainly to Norway) (CSB Latvia 2020a). According to the Central Statistical Bureau of Latvia, Latvian emigrants are generally very young, 55\% being aged between 20 and 39 years in 2018, slightly more men (54\%) than women (CSB Latvia 2020b). Almost one-third of Latvian emigrants are skilled and highly skilled individuals (Hazans 2018). However, the share of skilled and highly skilled Latvians differs by destination (from as low as 13\% in Ireland to $34 \%$ in the UK, and $21 \%$ in other EU/EFTA countries (Hazans 2015).

The proportion of highly educated people leaving Latvia increased significantly in 2009-2011 (Hazans 2018). The analysis of statistical data on migration of the highly educated reveals that besides the high share of young people, there are also gender differences. 
For example, in $2016,26 \%$ of emigrant women had a tertiary education, compared to $14 \%$ of emigrant men (CSB Latvia 2018). Highly educated emigrants are overrepresented in Science, Mathematics, IT and Medicine, and in Humanities and the Arts. Over the past decade, the nature of emigration has changed from short-term emigration to permanent emigration of the whole family. University graduates and minorities are over-represented among emigrants (Hazans 2018). Although emigration has declined since the years of the economic crisis, migration surpluses in Latvia remain negative (Hazans 2018).

When looking at the gender dimension of migration studies in Latvia, one finds it has not yet been explored in detail in the context of Latvian migrants. Several important studies have been devoted to the labor migration of ageing women and the migration of grandmothers (Lulle 2014, 2018; Lulle and King 2016). Despite the mentioned studies, in general one can say that the issue of highly educated female migration and perceived discrimination has not been sufficiently examined in Latvian migration research.

\subsection{Sampling and Data Collection}

The data source used for the analysis was a quantitative survey of Latvian emigrants, organized from August to October 2014. The data collection method was an online Internet-based survey method, which has been considered an appropriate data collection method to obtain a geographically dispersed, large sample under strict time constraints (Sue and Ritter 2012; McGhee et al. 2017; McCollum et al. 2017). In order to acquire more respondents, a diverse set of respondent recruitment channels was used: diaspora organizations, diaspora media, the largest social networking sites (draugiem.lv; Facebook, odnoklassniki, vkontakte), the largest online news portals in Latvia, and Latvian embassies abroad. A total of 14,068 Latvians living abroad participated. For the purposes of analysis, a subsample of highly skilled Latvian women was developed, based on the interpretation that a highly skilled migrant is a migrant with a tertiary education. This subsample $(n=2332)$ included only those Latvian women with a tertiary education who are first-generation emigrants from Latvia and who were working at the time of the survey. The representativeness of the survey was limited by the data-collection method and selfselection of respondents to participate in the online survey. Nevertheless, the survey had the widest possible geographic coverage, and in total 118 countries were represented in the data set. Table 1 presents a description of respondents according to host country, age, education, family status and time of emigration.

Table 1. Respondents (women with a tertiary education) according to host country, age, education, family status and time of emigration $(\mathrm{N}=2332)$.

\begin{tabular}{|c|c|c|}
\hline Host Country & $\%$ & $\mathbf{N}$ \\
\hline UK & $27 \%$ & 640 \\
\hline Germany & $10 \%$ & 242 \\
\hline Ireland & $6 \%$ & 137 \\
\hline Norway & $6 \%$ & 146 \\
\hline USA, Canada, Australia, New Zealand & $10 \%$ & 242 \\
\hline Nordic states, except Norway & $10 \%$ & 207 \\
\hline CIS states and Georgia & $4 \%$ & 85 \\
\hline Southern European states & $5 \%$ & 122 \\
\hline Western European states, except the UK, Germany and Ireland & $16 \%$ & 373 \\
\hline Eastern European states & $3 \%$ & 68 \\
\hline Other countries & $3 \%$ & 70 \\
\hline \multicolumn{3}{|l|}{ Age } \\
\hline $20-24$ & $4 \%$ & 101 \\
\hline $25-34$ & $46 \%$ & 1063 \\
\hline $35-44$ & $26 \%$ & 602 \\
\hline $45-54$ & $17 \%$ & 404 \\
\hline $55+$ & $7 \%$ & 162 \\
\hline
\end{tabular}


Table 1. Cont.

\begin{tabular}{|c|c|c|}
\hline Host Country & $\%$ & $\mathbf{N}$ \\
\hline \multicolumn{3}{|l|}{ Education (more than one answer possible) } \\
\hline Social Sciences, commercial and law & $44 \%$ & 1015 \\
\hline Humanities and art & $21 \%$ & 500 \\
\hline Engineering, manufacturing and construction & $6 \%$ & 151 \\
\hline Education science & $11 \%$ & 257 \\
\hline Healthcare and social welfare & $11 \%$ & 254 \\
\hline Natural sciences, mathematics and information technologies & $7 \%$ & 164 \\
\hline Agriculture & $2 \%$ & 39 \\
\hline Services & $5 \%$ & 111 \\
\hline \multicolumn{3}{|l|}{ Level of education } \\
\hline Master's degree & $33 \%$ & 780 \\
\hline Doctoral degree & $2 \%$ & 54 \\
\hline Highly skilled STEM with Master and Doctoral degree & $6 \%$ & 151 \\
\hline Live with partner & $59 \%$ & 1383 \\
\hline Has children & $29 \%$ & 679 \\
\hline \multicolumn{3}{|l|}{ Time of emigration } \\
\hline Before 2004 & $21 \%$ & 500 \\
\hline Between 2004-2008 & $24 \%$ & 563 \\
\hline After 2008 & $54 \%$ & 1267 \\
\hline
\end{tabular}

It is worth highlighting that, first, $29 \%$ of respondents have children and $59 \%$ live with a partner or spouse. All in all, the share of mixed marriages was rather high among Latvian emigrants, especially women (Klave and Šūpule 2017). In this sample of Latvian women with a tertiary education, of all respondents, $20 \%$ had an ethnic Latvian partner, $5 \%$ an ethnic Russian partner and 35\% a partner of a different ethnicity. While $75 \%$ of respondents acquired their education certificate in Latvia, 25\% received a degree abroad. In total, $71 \%$ of respondents had working experience in Latvia, but there was limited information about their professional experience, particularly in the field of their education. Although a lack of professional experience in home country could be one of the reasons leading to the over-qualification problem at host economies and self-perceived discrimination (Coniglio and Brzozowski 2018), the data availability limited the possibility to test this hypothesis.

\subsection{Measurement and Methods}

Binary logistic regression analyses were employed to test hypotheses on the effects of migrants' economic integration and attachment to host and home countries on perceived employment discrimination. Decisions regarding the variables to be included in the analysis were made on the basis of both theoretical and data-driven considerations. In total, three dependent variables were included in the analysis: (1) perceived unfair treatment when unpleasant and /or unprofitable tasks were assigned more frequently than to hostcountry nationals (perceived discrimination regarding work tasks); (2) perceived unfair treatment when there was pressure to take annual leave during the 'off season' (perceived discrimination regarding vocations); (3) perceived unfair treatment when paid less than host-country nationals for similar work (perceived wage discrimination).

Independent variables were grouped in three sets of variables, which were used to predict which individuals are more likely to experience perceived unfair treatment. The first set of variables consisted of background characteristics: age, occupational status, education in STEM areas (Science, Technology, Engineering, and Mathematics), host country and workplace industry (Table 2). Host country variables were included in the analysis to reveal if living and working in particular countries predicted the odds of perceived unfair treatment of women with a tertiary education. Workplace industry variables were included in the analysis to reveal if a workplace in the particular industry predicted the odds of perceived unfair treatment of women with a tertiary education. All in all, nine groups of industries were included in the analysis. In the initial regression models several other 
variables were tested: having children, the ethnicity of partners, the ethnicity of Latvian migrants (ethnic Latvian, ethnic Russian, and other ethnicity), living in a city or village in a host country. The odds of perceived discrimination were not affected by these variables. Therefore, they were not included in the final equation of the regression analyses.

Table 2. Descriptive statistics of the dependent and independent variables $(\mathrm{N}=2332)$ and a summary of measurement of variables.

\begin{tabular}{|c|c|c|c|}
\hline Variables & $\%$ & $\mathbf{N}$ & Summary of Measurement of Variables \\
\hline \multicolumn{4}{|l|}{ Dependent variables } \\
\hline $\begin{array}{l}\text { Has experienced that unpleasant and/or } \\
\text { unprofitable tasks are given more frequently than to } \\
\text { host-country nationals }\end{array}$ & $5 \%$ & 121 & $\begin{array}{l}\text { Dummy variable being } 1 \text { if the respondent has experienced } \\
\text { that unpleasant and/or unprofitable tasks are given more } \\
\text { frequently than to host-country nationals }\end{array}$ \\
\hline $\begin{array}{l}\text { Has experienced a push to take annual leave during } \\
\text { 'off season' }\end{array}$ & $8 \%$ & 178 & $\begin{array}{l}\text { Dummy variable being } 1 \text { if the respondent has experienced } \\
\text { a push to take annual leave during 'off season' }\end{array}$ \\
\hline $\begin{array}{l}\text { Is paid less than host-country nationals for } \\
\text { similar work }\end{array}$ & $9 \%$ & 203 & $\begin{array}{l}\text { Dummy variable being } 1 \text { if the respondent has been paid } \\
\text { less than host-country nationals for similar work }\end{array}$ \\
\hline \multicolumn{4}{|l|}{ Independent variables: the first set } \\
\hline Age & & & $\begin{array}{l}\text { Control variable. Age in years. Respondents' ages ranged } \\
\text { from } 20 \text { to } 75 \text { (mean 37.15). }\end{array}$ \\
\hline Self-employed or working in family business & $9 \%$ & 201 & $\begin{array}{l}\text { Dummy variable being } 1 \text { if the respondent is self-employed } \\
\text { or working in family business }\end{array}$ \\
\hline Entrepreneurs & $3 \%$ & 73 & Dummy variable being 1 if respondent is entrepreneur \\
\hline Highly skilled STEM with Master or Doctoral degree & $6 \%$ & 151 & $\begin{array}{l}\text { Dummy variable being } 1 \text { if the respondent has a Master or } \\
\text { Doctoral degree in STEM fields }\end{array}$ \\
\hline Host country: UK & $27 \%$ & 640 & Dummy variable being 1 if the respondent lives in the UK \\
\hline Host country: Germany & $10 \%$ & 242 & Dummy variable being 1 if the respondent lives in Germany \\
\hline Host country: Ireland & $6 \%$ & 137 & Dummy variable being 1 if the respondent lives in Ireland \\
\hline Host country: Norway & $6 \%$ & 146 & Dummy variable being 1 if the respondent lives in Norway \\
\hline Host country: USA, Canada, Australia, New Zealand & $10 \%$ & 242 & $\begin{array}{l}\text { Dummy variable being } 1 \text { if the respondent lives in the USA, } \\
\text { Canada, Australia, New Zealand }\end{array}$ \\
\hline Host country: Nordic states, except Norway & $10 \%$ & 207 & $\begin{array}{l}\text { Dummy variable being } 1 \text { if the respondent lives in the } \\
\text { Nordic states, except Norway }\end{array}$ \\
\hline Host country: CIS states and Georgia & $4 \%$ & 85 & $\begin{array}{l}\text { Dummy variable being } 1 \text { if the respondent lives in the CIS } \\
\text { states and Georgia }\end{array}$ \\
\hline Host country: Southern European states & $5 \%$ & 122 & $\begin{array}{l}\text { Dummy variable being } 1 \text { if the respondent lives in the } \\
\text { Southern European states }\end{array}$ \\
\hline $\begin{array}{l}\text { Host country: Western European states, except the } \\
\text { UK, Germany, and Ireland }\end{array}$ & $16 \%$ & 373 & $\begin{array}{l}\text { Dummy variable being } 1 \text { if the respondent lives in the } \\
\text { Western European states, except the UK, Germany, } \\
\text { and Ireland }\end{array}$ \\
\hline Host country: Eastern European states & $3 \%$ & 68 & $\begin{array}{l}\text { Dummy variable being } 1 \text { if the respondent lives in the } \\
\text { Eastern European states }\end{array}$ \\
\hline Workplace industry: Agriculture, forestry, fisheries & $2 \%$ & 49 & $\begin{array}{l}\text { Dummy variable being } 1 \text { if the respondent has a workplace } \\
\text { in agriculture, forestry, fisheries }\end{array}$ \\
\hline Workplace industry: Manufacturing and energy & $6 \%$ & 152 & $\begin{array}{l}\text { Dummy variable being } 1 \text { if the respondent has a workplace } \\
\text { in manufacturing and energy }\end{array}$ \\
\hline Workplace industry: Construction & $2 \%$ & 51 & $\begin{array}{l}\text { Dummy variable being } 1 \text { if the respondent has a workplace } \\
\text { in construction }\end{array}$ \\
\hline Workplace industry: Trade, catering and hospitality & $18 \%$ & 412 & $\begin{array}{l}\text { Dummy variable being } 1 \text { if the respondent has a workplace } \\
\text { in trade, catering and hospitality }\end{array}$ \\
\hline
\end{tabular}


Table 2. Cont.

\begin{tabular}{|c|c|c|c|}
\hline Variables & $\%$ & $\mathbf{N}$ & Summary of Measurement of Variables \\
\hline \multicolumn{4}{|l|}{ Independent variables: the first set } \\
\hline Workplace industry: Transport and logistics & $3 \%$ & 72 & $\begin{array}{l}\text { Dummy variable being } 1 \text { if the respondent has a workplace } \\
\text { in transport and logistics }\end{array}$ \\
\hline Workplace industry: IT and telecommunications & $7 \%$ & 165 & $\begin{array}{l}\text { Dummy variable being } 1 \text { if the respondent has a workplace } \\
\text { in IT and telecommunications }\end{array}$ \\
\hline $\begin{array}{l}\text { Workplace industry: Finances, insurance, science, } \\
\text { administration, and realtor services }\end{array}$ & $9 \%$ & 215 & $\begin{array}{l}\text { Dummy variable being } 1 \text { if the respondent has a workplace } \\
\text { in finances, insurance, science, administration, } \\
\text { and realtor services }\end{array}$ \\
\hline Workplace industry: Education & $9 \%$ & 213 & $\begin{array}{l}\text { Dummy variable being } 1 \text { if the respondent has a workplace } \\
\text { in education }\end{array}$ \\
\hline Workplace industry: Health and social care & $14 \%$ & 337 & $\begin{array}{l}\text { Dummy variable being } 1 \text { if the respondent has a workplace } \\
\text { in health and social care }\end{array}$ \\
\hline \multicolumn{4}{|l|}{ Independent variables: the second set } \\
\hline Plans to return in 5 years & $13 \%$ & 313 & $\begin{array}{l}\text { Dummy variable being } 1 \text { if the respondent has plans to } \\
\text { return to Latvia in } 5 \text { years }\end{array}$ \\
\hline $\begin{array}{l}\text { Has had problems abroad with recognition of } \\
\text { education certificate }\end{array}$ & $11 \%$ & 223 & $\begin{array}{l}\text { Dummy variable being } 1 \text { if the respondent has had } \\
\text { problems abroad with recognition of education certificate }\end{array}$ \\
\hline $\begin{array}{l}\text { Uses qualification/ education in current job to a } \\
\text { great extent }\end{array}$ & $52 \%$ & 1200 & $\begin{array}{l}\text { Dummy variable being } 1 \text { if the respondent uses } \\
\text { qualification/ education in current job to a great extent }\end{array}$ \\
\hline $\begin{array}{l}\text { Has improved professional knowledge in courses or } \\
\text { in-service learning }\end{array}$ & $52 \%$ & 1206 & $\begin{array}{l}\text { Dummy variable being } 1 \text { if the respondent has improved } \\
\text { professional knowledge in courses or in-service learning }\end{array}$ \\
\hline Has a written contract with employer & $76 \%$ & 1763 & $\begin{array}{l}\text { Dummy variable being } 1 \text { if the respondent has a written } \\
\text { contract with employer }\end{array}$ \\
\hline $\begin{array}{l}\text { Has had financial difficulties to cope with daily } \\
\text { expenses in Latvia before emigration }\end{array}$ & $68 \%$ & 1588 & $\begin{array}{l}\text { Dummy variable being } 1 \text { if the respondent has had financial } \\
\text { difficulties to cope with daily expenses in Latvia } \\
\text { before emigration }\end{array}$ \\
\hline $\begin{array}{l}\text { Has financial difficulties to cope with } \\
\text { daily expenses now }\end{array}$ & $9 \%$ & 220 & $\begin{array}{l}\text { Dummy variable being } 1 \text { if the respondent has had financial } \\
\text { difficulties to cope with daily expenses now }\end{array}$ \\
\hline \multicolumn{4}{|l|}{ Independent variables: the third set } \\
\hline Attachment to host country & & & $\begin{array}{l}\text { REGR factor score. Six indicators of attachment to the host } \\
\text { country were included in the factor analysis (see Table } 3 \text { ) }\end{array}$ \\
\hline Attachment to home country & & & $\begin{array}{l}\text { REGR factor score. Six indicators of attachment to the home } \\
\text { country were included in the factor analysis (see Table } 3 \text { ) }\end{array}$ \\
\hline
\end{tabular}

The second set of predictors referred to the economic integration and variables characterizing the working life of Latvian women emigrants with a tertiary education. This analysis distinguished between migrants' economic integration and sociocultural integration. Economic integration in this study referred to migrants' participation in the labor market, income and qualification, while sociocultural integration pertained to feelings of belonging and attachment to the host country. Bearing in mind that the term "integration" is a highly contested concept, this paper did not participate in the complex debate on terms of "assimilation" and "integration", but used the operational definition of integration as adaptation of migrants to majority society and culture (de Haas and Fokkema 2011). Regarding the economic integration and variables characterizing working life of Latvian women emigrants with a tertiary education, it should be said that all respondents included in the sample were working at the time of the survey and in general can be regarded as integrated in the labor market. However, some have encountered a problem with recognition of their education certificate $(11 \%)$, therefore the variable of having problems abroad with recognition of an education certificate was included in the analysis. Another problem faced 
by emigrants is brain waste, when emigrants have no possibility to use their qualification at their work. The variable used in the analysis referred to the group of emigrants who do use their qualification or education at their current job to any great extent (52\%). More than half of Latvian women emigrants with a tertiary education improved their professional knowledge or language skills in courses or in-service learning (52\%). The variable on participation in courses or in-service learning was included in the analysis to reveal if participation in professional and language trainings predicted the odds of perceived unfair treatment of women with a tertiary education.

In some countries undocumented emigrants who work without a written contract with the employer are more often the subjects of discrimination, therefore the variable of having a written contract with the employer was included in the analysis.

The questionnaire included several questions on the income situation of emigrants before and after emigration. One of the variables included in the analysis referred to the group of emigrants who report that they are currently having financial difficulties coping with daily expenses while living in emigration (9\%). Another variable refers to the group of emigrants who report that they have had financial difficulties coping with daily expenses in Latvia before emigration (68\%). The variable about plans to return to Latvia also was included in this set of variables, to find out if intentions to return predict the likelihood of perceived unfair treatment.

The third set of predictors captured attachment towards the host country and attachment to the country of origin - Latvia or the home country. Here and throughout the paper the term "home country" is used to refer to the country of origin of Latvian emigrants. The questionnaire used in this study included several items measuring attachment towards the host country and also several items measuring attachment to the home country. To reduce the number of variables, factor analysis was used. In total, six indicators of attachment to the host country were included in the factor analysis. A similar number of indicators was used also for the factor analysis of attachment to the country of origin (Table 3). Factor scores of two separate factor analyses were used as variables to find out if attachment towards the host country and attachment to the country of origin predict the odds of perceived unfair treatment.

Table 3. Empirical measures of attachment to the host country and home country (factor loadings).

\begin{tabular}{lc}
\hline Attachment to Host Country & \\
\hline Feels close ties to host country (1_yes) & 0.711 \\
Feels affiliated with the people of the host country (1_yes) & 0.705 \\
Follows the news of the host country (1_yes, regularly) & 0.636 \\
Follows the culture of the host country (1_yes, regularly) & 0.489 \\
Has close friends among natives in the host country (1_yes) & 0.475 \\
Knows most people in the neighbourhood in the host country (1_yes) & 0.439 \\
Eigenvalue & 2.065 \\
Variance explained (\%) & $34 \%$ \\
\hline Attachment to Home Country & \\
\hline Feels close ties to Latvia (1_yes) & 0.656 \\
Feels affiliated with the Latvian people (1_yes) & 0.651 \\
Follows Latvian culture (1_yes, regularly) & 0.635 \\
Follows Latvian news (1_yes, regularly) & 0.596 \\
Visits Latvia at least every half year (1_yes) & 0.476 \\
Has close friends in Latvia (1_yes) & 0.314 \\
Eigenvalue & 1.938 \\
Variance explained (\%) & $32 \%$ \\
\hline
\end{tabular}

\section{Results}

A total of three models of binary regression analysis of perceived discrimination at work reveal different indicators being significant in predicting one or another type of perceived unfair treatment at work. The variables in the equations of binary logistic regression 
analysis are presented in Table 4 (descriptive statistics of the dependent and independent variables are presented in Table 2). In the case of binary logistic regression analysis of perceived discrimination regarding work tasks, the Nagelkerke R Square value is 0.185 , indicating that $18.5 \%$ of the variance is explained by the model. In the cases of the two other dependent variables: perceived discrimination regarding vocations and perceived wage discrimination, the Nagelkerke R Square value is 0.147 and 0.133, respectively. Empirical findings are presented according to the three main sets of independent variables.

\subsection{Perceived Discrimination at Work and Background Characteristics}

The logistic regression model of perceived discrimination regarding work tasks indicates that age or living in the particular host country do not have any significant effect. After controlling for other factors, women who are working in manufacturing and energy industries are more likely to experience perceived discrimination regarding work tasks. The odds of perceived discrimination regarding work tasks decrease in those cases when women are self-employed or working in a family business (Table 4).

Different findings characterize two other logistic regression models of perceived unfair treatment. In the case of perceived discrimination regarding vocations, the age of the respondents had a certain influence, and older women were more likely to face such pressure. When looking at odds ratios of particular countries, we can see that those who live in the United States, Canada, Australia and New Zealand are less likely to experience perceived discrimination regarding vocations. The odds of pressure to take annual leave during the 'off season' increase in those cases when women are working in the trade, catering and hospitality industries.

Contrary to expectations, perceived wage discrimination has not been affected significantly by age or living in a particular host country. At the same time, we can see that the odds of perceived wage discrimination increase in particular industries. After controlling for other factors, women working in IT and telecommunications are more likely to experience a situation where they are paid less than host-country nationals for similar work. The odds of perceived wage discrimination also increase among women who work in the manufacturing and energy sectors, in health and social care and in the trade, catering and hospitality industries. 
Table 4. Determinants of perceived discrimination: three logistic regression models.

\begin{tabular}{|c|c|c|c|c|c|c|c|c|c|}
\hline & \multicolumn{3}{|c|}{$\begin{array}{l}\text { Has Experienced That Unpleasant and/or } \\
\text { Unprofitable Tasks Are Given More } \\
\text { Frequently Than to Host-Country Nationals }\end{array}$} & \multicolumn{3}{|c|}{$\begin{array}{l}\text { Has Experienced a Push to Take } \\
\text { Annual Leave during 'Off Season' }\end{array}$} & \multicolumn{3}{|c|}{$\begin{array}{l}\text { Is Paid Less Than } \\
\text { Host-Country Nationals for } \\
\text { Similar Work }\end{array}$} \\
\hline & B & S.E. & Sig. & B & S.E. & Sig. & B & S.E. & Sig. \\
\hline Age & 0.001 & 0.010 & 0.950 & 0.033 & 0.008 & 0.000 & 0.002 & 0.008 & 0.844 \\
\hline Self-employed or working in family business & -0.944 & 0.476 & 0.047 & -0.093 & 0.464 & 0.842 & -0.151 & 0.330 & 0.649 \\
\hline Entrepreneurs & -18.319 & 4359.378 & 0.997 & 0.496 & 0.556 & 0.373 & -0.321 & 0.527 & 0.543 \\
\hline \multicolumn{10}{|l|}{ Host country: } \\
\hline UK & 0.313 & 0.775 & 0.687 & 0.464 & 0.627 & 0.459 & -0.288 & 0.513 & 0.575 \\
\hline Germany & 0.831 & 0.806 & 0.303 & 0.723 & 0.653 & 0.268 & 0.548 & 0.533 & 0.304 \\
\hline Ireland & 0.568 & 0.850 & 0.504 & 0.737 & 0.676 & 0.275 & 0.029 & 0.580 & 0.960 \\
\hline Norway & 1.104 & 0.822 & 0.179 & 0.823 & 0.670 & 0.219 & -0.058 & 0.590 & 0.921 \\
\hline USA, Canada, Australia, New Zealand & 0.219 & 0.848 & 0.796 & -2.337 & 1.177 & 0.047 & -0.227 & 0.570 & 0.690 \\
\hline Nordic states, except Norway & 1.068 & 0.802 & 0.183 & 0.527 & 0.658 & 0.423 & 0.522 & 0.538 & 0.332 \\
\hline CIS states and Georgia & -17.188 & 4090.306 & 0.997 & -1.014 & 1.185 & 0.392 & -1.730 & 1.128 & 0.125 \\
\hline Southern European states & 0.535 & 0.856 & 0.532 & 0.945 & 0.681 & 0.165 & -0.249 & 0.602 & 0.679 \\
\hline Western European states, except the UK, Germany and Ireland & 0.224 & 0.802 & 0.780 & 0.490 & 0.637 & 0.442 & 0.501 & 0.512 & 0.327 \\
\hline Eastern European states & -0.457 & 1.274 & 0.720 & 0.682 & 0.808 & 0.399 & -0.725 & 0.878 & 0.409 \\
\hline \multicolumn{10}{|l|}{ Industry: } \\
\hline Agriculture, forestry, fisheries & -18.183 & 5406.302 & 0.997 & 0.813 & 0.448 & 0.070 & 0.765 & 0.464 & 0.099 \\
\hline Manufacturing and energy & 1.040 & 0.379 & 0.006 & -0.033 & 0.373 & 0.929 & 0.671 & 0.339 & 0.048 \\
\hline Construction & -17.657 & 5105.368 & 0.997 & -1.075 & 1.038 & 0.301 & 0.233 & 0.641 & 0.716 \\
\hline Trade, catering and hospitality & 0.418 & 0.319 & 0.190 & 0.704 & 0.245 & 0.004 & 0.559 & 0.250 & 0.026 \\
\hline Transport and logistics & 0.443 & 0.542 & 0.414 & 0.327 & 0.450 & 0.468 & -0.003 & 0.510 & 0.996 \\
\hline IT and telecommunications & 0.720 & 0.475 & 0.129 & -0.826 & 0.549 & 0.133 & 0.864 & 0.338 & 0.011 \\
\hline Finances, insurance, science, administration and realtor services & 0.074 & 0.467 & 0.874 & 0.016 & 0.344 & 0.963 & 0.233 & 0.340 & 0.494 \\
\hline Education & 0.432 & 0.397 & 0.277 & 0.174 & 0.318 & 0.583 & 0.328 & 0.321 & 0.307 \\
\hline Health and social care & 0.399 & 0.339 & 0.239 & -0.274 & 0.291 & 0.348 & 0.625 & 0.258 & 0.015 \\
\hline Plans to return in 5 years & 0.293 & 0.264 & 0.266 & 0.256 & 0.241 & 0.286 & 0.633 & 0.205 & 0.002 \\
\hline
\end{tabular}


Table 4. Cont.

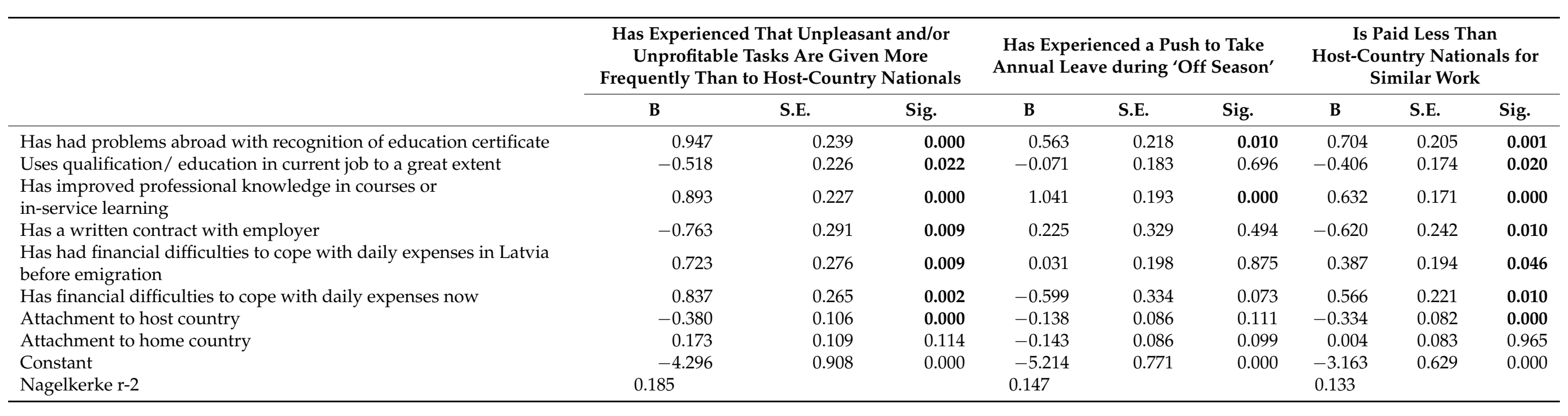




\subsection{Perceived Discrimination at Work, Economic Integration and Professional Education}

When reporting empirical findings regarding economic integration, it should be stressed that all respondents included in the sample were working Latvian emigrants with a tertiary education, which means that this group can be characterized as integrated in the host countries' labor market. However, when asked about their financial situation, $9 \%$ of respondents reported financial difficulties coping with daily expenses. In comparison, $68 \%$ of respondents reported financial difficulties coping with daily expenses in Latvia before emigration. After controlling for other factors, women who have financial difficulties coping with daily expenses are more likely to experience perceived discrimination regarding work tasks. Similarly, women who have had financial difficulties coping with daily expenses in Latvia before emigration are also more likely to experience perceived discrimination regarding work tasks.

It is believed that employees who have a written contract with employers enjoy more social security than those without a contract, and that they have stronger confidence in the legality of their employment relations (Halaby 1986). Among surveyed Latvian emigrant women, $76 \%$ have a written contract with the employer. After controlling for other factors, women who have a written contract with the employer are less likely to experience perceived discrimination regarding work tasks. When looking deeper to answer the question of who are the individuals working without any written contract, it appears that the self-employed, those working in a family business and entrepreneurs are most likely to have no written contract. Most likely that they have encountered unfair treatment at the workplace before becoming self-employed. This group forms about one-third of those working without any written contract. Women with a tertiary education working in engineering, manufacturing and construction, agriculture, IT and telecommunication industries are more likely to work without a written contract. In total, two-thirds or $64 \%$ of those working without any written contract do not use their qualification or education in their current job.

Another hypothesis tested is about the use of qualification/education in the current job and problems with recognition of an education certificate. Among surveyed Latvian emigrant women with a tertiary education, $52 \%$ use their qualification/education in their current job and $11 \%$ have had problems with recognition of an education certificate in the host country. After controlling for other factors, women who use their qualification/education in the current job are less likely to experience perceived discrimination regarding work tasks. By contrast, women who have had problems with recognition of an education certificate in the host country are more likely to experience perceived discrimination regarding work tasks. The odds of perceived unfair treatment regarding unpleasant tasks also increase if the woman has improved professional knowledge in courses or in-service learning.

Similar effects of analyzed indicators pertain to the odds of perceived wage discrimination. After controlling for other factors, women who have financial difficulties coping with daily expenses and women who have had financial difficulties coping with daily expenses in Latvia before emigration are more likely to experience perceived wage discrimination. Women who have a written contract with the employer and who use their qualification/education in the current job are less likely to experience perceived wage discrimination. Women who have had problems with recognition of an education certificate in the host country and who have improved professional knowledge in courses or in-service learning are more likely to experience perceived unfair treatment when paid less.

Interestingly, in the case of perceived discrimination regarding vocations, only two of the mentioned indicators are significant: (1) has had problems abroad with recognition of an education certificate, and (2) has improved professional knowledge in courses or in-service learning. The odds of perceived discrimination regarding vocations increase in both situations.

After controlling for other factors, women who plan to return to Latvia in the next 5 years are more likely to experience perceived wage discrimination. These findings suggest 
that return intentions have a correlation with perceived discrimination. This could be one of the explanations for out-migration from host countries, and in the context of understanding settlement or circular migration, it would be important to study this in-depth.

\subsection{Perceived Discrimination at Work and Attachment to the Host and Home Countries}

To find the factors for attachment to the host and home countries, two factor analyses were carried out. The factor "attachment to the host country" has an eigenvalue of 2065 and explains $34 \%$ of the variance in the six indicators mentioned (Table 3). The factor "attachment to the home country" has an eigenvalue of 1938 and explains $32 \%$ of the variance among the six indicators mentioned.

The logistic regression model of perceived unfair treatment confirms the hypothetical assumption that those who don't have a strong attachment to the host country are more likely to experience perceived discrimination. The beta weights presented in Table 4 reveal that the odds of perceived discrimination regarding work tasks decrease if the woman has a strong attachment to the host country. Similarly, the odds of perceived wage discrimination also decrease if the woman has a strong attachment to the host country. At the same time, attachment to the host country has no significant effect on perceived discrimination regarding vocations.

Contrary to expectations, attachment to the home country does not have any significant effects on perceived discrimination. These findings confirm that attachment to the home country and attachment to the host country are two independent variables.

\section{Discussion}

This study highlights the phenomenon of perceived discrimination in the workplace and the factors that lead to an increase or decrease in perceived discrimination in the workplace. The analysis is focused on one particular group - highly educated Latvian womenthat has been neglected in previous studies on perceived discrimination. The quantitative analysis of this study offers several general findings.

First, binary logistic regression analyses show that perceived discrimination at work is a complex phenomenon, which should not be analyzed as a single category. Perceived discrimination or unfair treatment in the workplace in this study was operationalized, and three items were included in the analysis: (1) perceived unfair treatment when unpleasant and/or unprofitable tasks were assigned more frequently than to host-country nationals; (2) perceived unfair treatment when the individual felt pressure to take annual leave during the 'off season'; (3) perceived unfair treatment when the individual was paid less than host-country nationals for similar work. A total of three separate binary logistic regression analyses reveal that different factors lead to an increase or decrease in perceived discrimination in the workplace in respect to three types of perceived discrimination.

Second, the findings regarding the relationship between attachment to the host country and perceived discrimination reveal support for the assimilation theory. In total, two out of three binary logistic regression analyses indicate that those migrants who feel less attached to the host society will more often report perceived discrimination, particularly regarding work tasks and wage. Attachment to the home country does not have any significant effects on perceived discrimination. In the context of the studies on transnationalism among migrants (Levitt and Glick Schiller 2004; de Haas and Fokkema 2011; Waldinger 2017), these findings confirm that attachment to the home country and attachment to the host country are two independent variables. Strong attachment to the host country does not exclude the possibility of having a strong attachment to the country of origin.

Third, the perception of the financial situation before emigration and at the moment of survey are related to perceived discrimination at work. However, the findings reveal mixed patterns in respect of different forms of perceived discrimination at work. Women who have financial difficulties coping with daily expenses are more likely to experience perceived discrimination regarding work tasks and perceived wage discrimination. Nevertheless, they are less likely to experience pressure to take annual leave during the 'off season'. 
Women who have had financial difficulties coping with daily expenses before emigration also are more likely to experience perceived discrimination regarding work tasks and wage.

Fourth, a written contract with the employer has a significant impact on perceived discrimination at work. Women who have a written contract with the employer are less likely to experience perceived discrimination regarding work tasks or wage. This confirms that employees who have a written contract with employers have stronger confidence in the legality of their employment relations, and this diminishes the likelihood of perceived discrimination in the workplace.

Fifth, problems with the recognition of an education certificate have a significant impact on perceived discrimination at work, and findings support this statement regarding all three types of perceived discrimination analyzed. Women who have had problems with recognition of an education certificate in the host country are more likely to experience perceived unfair treatment. Although the right of Europeans to pursue economic activities in another EU country is a fundamental right enshrined in the Treaty on the Functioning of the European Union, there are some obstacles regarding the free movement of professionals in the EU, because each country may allow access to a particular profession only if the individual has a specific professional qualification, i.e., the qualification acquired in the particular country. The system of recognition of professional qualifications in the EU aims to minimize these obstacles and is governed by Directive 2005/36/EC, recently amended by Directive 2013/55/EU. The directive provides a modern EU system of recognition of professional experience and promotes automatic recognition of professional experience across the EU. The professions that benefit from automatic recognition based on harmonized minimum training requirements under the directive are nurses, midwives, doctors (basic medical training, general practitioners, and specialists), dental practitioners, pharmacists, architects and veterinary surgeons. Some professions such as sailors or aircraft controllers (in principle) do not fall under the recognition procedures of Directive 2005/36/EC and are governed by specific legislation. Special laws also exist for lawyers (European Commission 2020). Despite the rules that the EU has set up to ensure that the Member States fully test how professions are regulated in terms of whether they are non-discriminatory, subjective non-recognition of diplomas may exist as well. In the case of Latvian women migrants with tertiary education, $44 \%$ have an education in social sciences, business and law, and $22 \%$ in humanities and art. These are diplomas which are more difficult to apply in other countries if a migrant has no social and cultural host capital (Csedö 2008; Coniglio and Brzozowski 2018) and may cause a subjective perception of non-recognition of education abroad. However, discrimination on the grounds of ethnicity or national origin may also play a part (Schmidtke 2013).

One of the indicators characterizing the phenomenon of brain waste abroad is the situation when a migrant does not use his or her qualification or education on the job. The findings of the study show that women who use their qualification/education in their current job are less likely to experience perceived discrimination regarding work tasks or perceived wage discrimination. Unfortunately, the study does not provide answers to the question of why highly educated Latvian women do not use their qualifications or education. Due to data limitations, the possible answers suggested in other studies (lack of host-country-specific skills, particularly, language skills (Csedö 2008; Coniglio and Brzozowski 2018), the low level of professional skills due to lack of professional experience (Iglicka 2010; Kaczmarczyk 2018)) have not been tested. However, these answers could also shed more light on the phenomenon of perceived discrimination.

Finally, it should be stressed that living in a particular host country or being a particular age do not have any significant effect on perceived discrimination among women with a tertiary education, but working in a particular industry does, especially on perceived wage discrimination. Women working in IT and telecommunications; the manufacturing and energy sectors; health and social care; and the trade, catering and hospitality industries are more likely to experience a situation where they are paid less than host-country nationals for similar work. 


\section{Conclusions}

The study allows a number of policy conclusions to be drawn. First, in the context of non-discrimination policies stipulated and implemented by the countries and employers at the workplace, on the books these policies usually are consistent with obligations under the law and prohibit unlawful discrimination on the basis of race, color, national or ethnic origin, sex, age, disability, religion, sexual orientation or any other characteristic protected by applicable law. However, as stressed by Schuck (2000), "law on the books" differs from "law in action" and "law in their minds". Therefore it is not sufficient to have a nondiscrimination law or for companies to have non-discrimination policies. It is important that employees have the possibility to voice their concerns and file complaints without fear of retaliation. It is also important that employees with questions or concerns about any type of discrimination in the workplace be encouraged to bring these issues to the attention. Particular attention should be paid to non-discrimination training to spot discrimination and empower individuals to report on instances of discrimination. It would be useful to develop information about possibilities for reporting on cases where discrimination has been encountered, and even creating special, anonymized reporting opportunities.

In the case of migrant women, another finding points to the role of a written contract with the employer in building stronger confidence in the legality of the employment relations. These findings suggest a recommendation to support activities aiming to inform employees about the benefits when having a written contract, which allows avoiding many misunderstandings and, consequently, perceived discrimination. Information is also needed about the organizations where one can complain if an employer does not want to enter into a contract.

The problems with recognition of an education certificate acquired abroad is another issue that is yet to be solved. Although this is only a problem in some very regulated professions, for example, for medical personnel and attorneys, the study points out that this issue is important in the context of non-discrimination policies. In some cases, agreements between the host and the sending states on bilateral solutions for recognition of education could foster recognition of an education certificate acquired abroad and help preventing brain waste and discrimination in the labor market.

Finally, in the case of migrant women, the study shows that working in a particular industry has a significant effect on perceived discrimination among Latvian migrant women with a tertiary education. Therefore, special attention should be paid to the nondiscrimination policies of particular industries, where migrant women are paid less than host-country nationals for similar work, and these industries are IT and telecommunications, the manufacturing and energy sectors, health and social care and the trade, catering and hospitality sectors.

When reflecting on some limitations of the study, the problem of causality should be mentioned. For example, the findings show that those migrants who feel less attached to the host society more often report on perceived discrimination, and this suggests that attachment to the host country affects the perception of discrimination. However, the opposite may be true as well, because perceived discrimination may hamper the development of attachment to the host country. Another example is in regard to return-migration intentions. The findings reveal that women who plan to return to Latvia in the next 5 years are more likely to experience perceived unfair treatment when paid less than host-country nationals for similar work. However, probably the causality is opposite, and women who experience perceived unfair treatment when paid less are more likely to consider returning to the country of origin.

In the case of this study, data availability also limits the scope of analysis. For example, the survey does not provide information on the actual amount of salaries of highly educated Latvian emigrant women, their professional experience before migration and why highly educated Latvian women do not use their qualifications or education. Therefore, further studies are needed to reveal other aspects that explain the perceived discrimination of highly educated Latvian emigrant women. A more nuanced approach is needed 
to understand how these women combine their domestic roles with paid employment. As mixed marriages are increasingly common among emigrant women from Latvia as well as among Polish women (Klave and Šūpule 2017; Slany 2018), it would be useful to scrutinize if there are any important differences in the composition and lifestyle of families in Latvia and abroad, and how this impacts perceived discrimination. Moreover, the comparison of perceived discrimination among emigrant women with a tertiary education from Latvia with women with a tertiary education in Latvia would provide a deeper understanding of the phenomenon. Future studies should also pay more attention to the relationship between highly-skilled migration, gender and migrant entrepreneurship. Although this analysis showed that perceived discrimination regarding work tasks decreases in those cases when women are self-employed or working in a family business, these findings should be replicated and extended in other geographical contexts. Much still remains to be explored regarding emigrant women with a tertiary education and perceived discrimination among them.

Funding: This work was supported by the European Regional Development Fund, Activity 1.1.1.2 "Post-doctoral Research Aid" under Grant Nr. 1.1.1.2/VIAA/1/16/012, Project "Migration of highly qualified specialists: emigration and return migration in Latvia".

Conflicts of Interest: The author declares no conflict of interest. The funders had no role in the design of the study; in the collection, analyses, or interpretation of data; in the writing of the manuscript, or in the decision to publish the results.

\section{References}

Aguirre, Benigno Emilio, Rogelio Saenz, and Sean-Shong Hwang. 1989. Discrimination and the assimilation and ethnic competition perspectives. Social Science Quarterly 70: 1989-96.

Andriessen, Iris, Henk Fernee, and Karin Wittebrood. 2014. Perceived Discrimination in the Netherlands. The Hague: The Netherlands Institute for Social Research.

Bailey, Ajay, and Clara H. Mulder. 2017. Highly skilled migration between the Global North and South: Gender, life courses and institutions. Journal of Ethnic and Migration Studies 43: 2689-703. [CrossRef]

Boucher, Anna, and Lucie Cerna. 2014. Current policy trends in skilled immigration policy. International Migration 52: 21-25. [CrossRef]

Brüss, Joachim. 2008. Experiences of discrimination reported by Turkish, Moroccan and Bangladeshi Muslims in three European cities. Journal of Ethnic and Migration Studies 34: 875-94. [CrossRef]

Cerna, Lucie. 2011. Selecting the Best and the Brightest. Oxford: Policy Primer, University of Oxford.

Clark, Ken, and Stephen Drinkwater. 2008. The Labor-Market Performance of Recent Migrants. Oxford Review of Economic Policy 24: 496-517. [CrossRef]

Coniglio, Nicola Daniele, and Jan Brzozowski. 2018. Migration and development at home: Bitter or sweet return? Evidence from Poland. European Urban and Regional Studies 25: 85-105. [CrossRef]

CSB Latvia. 2018. Emigranta Portrets. 2014-2016. Available online: https://www.csb.gov.lv/lv/statistika/statistikas-temas/ iedzivotaji/migracija/meklet-tema/342-emigranta-portrets-2014-2016-gada (accessed on 20 October 2019).

CSB Latvia. 2020a. IBG020. International Long-Term Migration by Country Group. Available online: http:/ / data1.csb.gov.lv/pxweb/ en/iedz/search/?rxid=fd7c1a0db6fd-453b-ade1-f084b148d3c3\&searchquery=population (accessed on 15 May 2020).

CSB Latvia. 2020b. IBG040. International Long-Term Migrants by Age and Sex. Available online: https://data1.csb.gov.lv/pxweb/en/ iedz/iedz__migr/IBG040.px/ (accessed on 15 May 2020).

CSB Latvia. 2020c. ISG010. Population, Population Change, and Key Vital Statistics. Available online: http://data1.csb.gov.lv/pxweb/ en/iedz/iedz_iedzskaits_ikgad/ISG010.px/?rxid=fd7c1a0db6fd-453b-ade1-f084b148d3c3 (accessed on 15 May 2020).

Csedö, Krisztina. 2008. Negotiating Skills in the Global City: Hungarian and Romanian Professionals and Graduates in London. Journal of Ethnic and Migration Studies 34: 803-23. [CrossRef]

de Haas, Hein, and Tineke Fokkema. 2011. The effects of integration and transnational ties on international return migration intentions. Demographic Research 25: 755-82. [CrossRef]

Dustmann, Christian, Tommaso Frattini, and Caroline Halls. 2010. Assessing the Fiscal Costs and Benefits of A8 Migration to the UK. Fiscal Studies 31: 1-41. Available online: https://www.ucl.ac.uk/ \{\}uctpb21/Cpapers/DustmannFrattiniHalls2010.pdf (accessed on 17 September 2020). [CrossRef]

Estrada, Emily P., Yung-Mei Tsai, and Charles R. Chandler. 2008. Assimilation and discriminatory perceptions and experiences: The case of Hispanics in the United States. The Social Science Journal 45: 673-81. [CrossRef]

European Commission. 2020. USER GUIDE. Directive 2005/36/EC. All You Need to Know about Recognition of Professional Qualifications. Luxembourg: Publications Office of the European Union. 
Ferrant, Gaëlle, and Michele Tuccio. 2015. South-South Migration and Discrimination against Women in Social Institutions: A Two-way Relationship. World Development 72: 240-54. [CrossRef]

Frattini, Tomasso, Ainhoa Aparicio Fenoll, and Karl Siragusa. 2017. Migration Observatory Report: Immigrants' Integration in Europe. Italy: Amici del Centro Studi Luca d'Agliano.

Gordon, Milton. 1964. Assimilation in American Life. The Role of Race, Religion, and National Origins. New York: Oxford University Press.

Grigoleit-Richter, Grit. 2017. Highly skilled and highly mobile? Examining gendered and ethnicised labor market conditions for migrant women in STEM professions in Germany. Journal of Ethnic and Migration Studies 43: 2738-55. [CrossRef]

Grzymała-Kazłowska, Aleksandra. 2013. Migration and Socio-Demographic Processes in Central and Eastern Europe: Characteristics, Specificity and Internal Differences. Central and Eastern European Migration Review 2: 5-11.

Halaby, Charles N. 1986. Worker attachment and workplace authority. American Sociological Review 51: 634-49. [CrossRef]

Hazans, Mihails. 2015. Brain drain from Latvia in the 21st century. In Latvian Emigrant Communities: The Diaspora of Hope. Edited by Inta Mierina. Riga: Institute of Philosophy and Sociology, University of Latvia, pp. 85-92. (In Latvian)

Hazans, Mihails. 2018. Latvia-An In-Depth Analysis of the Emigration of Skilled Labor. Brussels: European Centre of Expertise in the Field of Labor Law, Employment and Labor Market Policy, Available online: https:/ / ec.europa.eu/social/main.jsp?catId=738\& langId=en\&pubId=8132\&furtherPubs=yes (accessed on 20 October 2019).

ICF. 2018. Study on the Movement of Skilled Labor. Luxembourg: Publications Office of the European Union.

Iglicka, Krystyna. 2010. Powroty Polaków po 2004 roku: W pętli pułapki migracji. Warsaw: Wydawnictwo Naukowe Scholar.

IOM/OECD. 2014. Harnessing Knowledge on the Migration of Highly Skilled Women. Geneva: International Organization for Migration.

Jakubiak, Igor. 2015. Immigrants in the United Kingdom: Wage Gap and Origin. Ekonomia 43: 67-89. [CrossRef]

Kaczmarczyk, Pawel. 2018. Post-accession migration and the Polish labor market. Expected and unexpected effects. In The Impact of Migration on Poland EU Mobility and Social Change. Edited by Anne White, Izabela Grabowska, Pawel Kaczmarczyk and Krystyna Slany. London: UCL Press University College London, pp. 90-107.

Kaczmarczyk, Pawel, and Joanna Tyrowicz. 2015. Winners and Losers among Skilled Migrants: The Case of Post-Accession Polish Migrants to the UK. IZA Discussion Paper No. 9042. Bonn: Institute for the Study of Labor.

Klave, Evija, and Inese Šūpule. 2017. Latvian and Language Competition in the Diaspora (Emigrant Community). In Language Situation in Latvia: 2010-2015: A Sociolinguistic Study. Edited by Gunta Klava. Rīga: Latviešu valodas aǵentūra, pp. 123-55.

Kofman, Eleonore. 2014. Towards a gendered evaluation of (highly) skilled immigration policies in Europe. International Migration 52: 116-28. [CrossRef]

Levitt, Peggy, and Nina Glick Schiller. 2004. Conceptualizing simultaneity: A transnational social field perspective on society. International Migration Review 38: 1002-39. [CrossRef]

Lulle, Aija. 2014. Shifting notion of gendered care and neoliberal motherhood: Evidences from lives of Latvian migrant women in Guernsey. Women's Studies International Forum 47: 239-49. [CrossRef]

Lulle, Aija. 2018. Relational ageing: On intra-gender and generational dynamism amongst ageing Latvian women. Area 50: 452-58. [CrossRef]

Lulle, Aija, and Russell King. 2016. Ageing, Gender, and Labor Migration. New York: Mobility \& Politics, Palgrave Macmillan.

McCollum, David, Elina Apsite-Berina, Maris Berzins, and Zaiga Krisjane. 2017. Overcoming the Crisis: The Changing Profile and Trajectories of Latvian Migrants. Journal of Ethnic and Migration Studies 43: 1508-25. [CrossRef]

McGhee, Derek, Chris Moreh, and Athina Vlachantoni. 2017. An 'Undeliberate Determinacy'? The Changing Migration Strategies of Polish Migrants in the UK in Times of Brexit. Journal of Ethnic and Migration Studies 43: 2109-30. [CrossRef]

Mierina, Inta. 2016. Latvijas Diasporas Pieredze Saskarsmē ar Valsts Institūcijām un Darba Devējiem ārpus Latvijas. Rīga: LU Diasporas un migrācijas pētījumu centrs.

Mulholland, Jon, and Louise Ryan. 2014. Doing the business: Variegation, opportunity and intercultural experience among intra-EU highly-skilled migrants. International Migration 52: 55-68. [CrossRef]

OECD/EU. 2015. Indicators of Immigrant Integration 2015: Settling in. Paris: OECD Publishing.

Portes, Alejandro, Robert Nash Parker, and José A. Cobas. 1980. Assimilation or consciousness: Perceptions of U.S. society among recent Latin American immigrants to the United States. Social Forces 59: 200-24. [CrossRef]

Schmidtke, Oliver. 2013. Wasting Newcomers' Human Capital? Cultural Capital and the Integration of Skilled Migrants into the British and German Labor Markets. In Wanted and Welcome? Immigrants and Minorities, Politics and Policy. Edited by Triadafilos Triadafilopoulos. New York: Springer, pp. 287-304. [CrossRef]

Schuck, Peter H. 2000. Law and the study of migration. In Migration Theory: Talking across Disciplines. Edited by Caroline B. Brettell and James F. Hollifield. London: Routledge, pp. 187-203.

Slany, Krystyna. 2018. Family relations and gender equality in the context of migration. In The Impact of Migration on Poland EU Mobility and Social Change. Edited by Anne White, Izabela Grabowska, Pawel Kaczmarczyk and Krystyna Slany. London: UCL Press University College London, pp. 108-30.

Sue, Valerie M., and Lois A. Ritter. 2012. Conducting Online Surveys. Thousand Oaks: Sage.

Tabuns, Aivars. 2019. Latvian migrants in foreign labor markets: Job placement and discrimination. In The Emigrant Communities of Latvia: National Identity, Transnational Belonging, and Diaspora Politics. Edited by Rita Kaša and Inta Mierina. Cham: Springer International Publishing, pp. 97-115. 
Todaro, M. 1969. A Model of Labor Migration and Urban Unemployment in Less Developed Countries. The American Economic Review 59: $138-48$.

Triadafilopoulus, Triadafilos, ed. 2013. Wanted and Welcome? Policies for Highly Skilled Immigrants in Comparative Perspective. New York: Springer. [CrossRef]

Triandafyllidou, Anna, and Irina Isaakyan, eds. 2016. High-Skill Migration and Recession. Gendered Perspectives. London: Palgrave Macmillan. [CrossRef]

Vancluysen, Kris, and Maarten Van Craen. 2010. Integration and Perceived Discrimination: Two Competing Hypotheses Tested among Persons of Moroccan and Turkish Descent in Belgium. Paper presented at the QMSS2/ESF seminar 'Measuring Integration and Discrimination' INED, Paris, France, July 5-6.

Verwiebe, Roland, Lena Seewann, Margarita Wolf, and Melek Hacioglu. 2016. 'I have to be very good in what I do'. Marginalisation and discrimination in the career-entry phase-Experiences and coping strategies among university graduates with a migrant background in Austria. Journal of Ethnic and Migration Studies 42: 2468-90. [CrossRef]

Waldinger, Roger. 2017. A cross-border perspective on migration: Beyond the assimilation/ transnationalism debate. Journal of Ethnic and Migration Studies 43: 3-17. [CrossRef]

Waters, Mary C., and Philip Kasinitz. 2013. Immigrants in New York: Reaping the benefits of continuous immigration. Daedalus 142: 92-106. [CrossRef]

Yilmaz Sener, Meltem. 2019. Perceived discrimination as a major factor behind return migration? The return of Turkish qualified migrants from the USA and Germany. Journal of Ethnic and Migration Studies 45: 2801-19. [CrossRef] 